\title{
Erratum: Lye, Mukherjee, and Burns (2019)
}

The article by Lye, C.T., Mukherjee, S., \& Burns, S.F. (2019). Combining plant sterols with walking lowers postprandial triacylglycerol more than walking only in Chinese men with elevated body mass index. International Journal of Sport Nutrition and Exercise Metabolism, 29(6), 576-582, https://doi.org/10.1123/ijsnem.20180398, was originally published with the copyright assigned to Human Kinetics, Inc. Since publication, the authors have chosen to publish the article under the Creative Commons Attribution 4.0 International License. The online version of this article has been made open access and includes updated copyright language as follows:
(C) 2019 The Authors. Published by Human Kinetics, Inc. This is an Open Access article distributed under the terms of the Creative Commons Attribution 4.0 International License, CC BY 4.0 , which permits unrestricted noncommercial and commercial use, distribution, and reproduction in any medium, provided the original work is properly cited, the new use includes a link to the license, and any changes are indicated. See http:// creativecommons.org/licenses/by/4.0. This license does not cover any third-party material that may appear with permission in the article. 